Research Paper

\title{
Effect of Antisense Oligodeoxynucleotides Glucose Transporter-I on Enhancement of Radiosensitivity of Laryngeal Carcinoma
}

Sen-Xiang Yan ${ }^{1}$, Xing-Mei Luo ${ }^{1}$, Shui-Hong Zhou ${ }^{\circledR}{ }^{凶}$, Yang-Yang Bao², Jun Fan ${ }^{3}$, Zhong-Jie Lu' ${ }^{1}$, Xin-Biao Liao $^{1}$, Ya-Ping Huang'3 ${ }^{3}$ Ting-Ting $\mathrm{Wu}^{2}$, Qin-Ying Wang ${ }^{2}$

1. Department of Radiotherapy, The First Affiliated Hospital, College of Medicine, Zhejiang University, Hangzhou, Zhejiang, 310003, China

2. Department of Otolaryngology, The First Affiliated Hospital, College of Medicine, Zhejiang University, Hangzhou, Zhejiang, 310003,China

3. State Key Laboratory for Diagnosis and Treatment of Infectious Diseases, The First Affiliated Hospital, College of Medicine, Zhejiang University, Hangzhou 310003, China.

$\triangle$ Corresponding author: Shui-Hong Zhou. 79 Qingchun Road, Hangzhou City, Zhejiang Province, China, 310003. E-mail: zhouyunzhoush@163.com. Fax: 86-571-87236895. Tel: 86-571-87236894

() Ivyspring International Publisher. This is an open-access article distributed under the terms of the Creative Commons License (http://creativecommons.org/ licenses/by-nc-nd/3.0/). Reproduction is permitted for personal, noncommercial use, provided that the article is in whole, unmodified, and properly cited.

Received: 2013.06.07; Accepted: 2013.07.23; Published: 2013.08.21

\begin{abstract}
Purpose: Laryngeal carcinomas always resist to radiotherapy. Hypoxia is an important factor in radioresistance of laryngeal carcinoma. Glucose transporter-I (GLUT-I) is considered to be a possible intrinsic marker of hypoxia in malignant tumors. We speculated that the inhibition of GLUT-I expression might improve the radiosensitivity of laryngeal carcinoma. Methods: We assessed the effect of GLUT-I expression on radioresistance of laryngeal carcinoma and the effect of GLUT-I expressions by antisense oligodeoxynucleotides (AS-ODNs) on the radiosensitivity of laryngeal carcinoma in vitro and in vivo. Results: After transfection of GLUT-I AS-ODNs: MTS assay showed the survival rates of radiation groups were reduced with the prolongation of culture time $(p<0.05)$; Cell survival rates were significantly reduced along with the increasing of radiation dose $(p<0.05)$. There was significant difference in the expression of GLUT-I mRNA and protein in the same $X$-ray dose between before and after $X$-ray radiation $(p<0.05)$. In vivo, the expressions of GLUT-I mRNA and protein after 8Gy radiation plus transfection of GLUT-I AS-ODNs were significant decreased compared to $8 \mathrm{G}$ y radiation alone $(p<0.00 \mathrm{I})$. Conclusion: Radioresistance of laryngeal carcinoma may be associated with increased expression of GLUT-I mRNA and protein. GLUT-I AS-ODNs may enhance the radiosensitivity of laryngeal carcinoma mainly by inhibiting the expression of GLUT-I.
\end{abstract}

Key words: Laryngeal carcinoma, Glucose transporter-1, antisense oligodeoxynucleotides, Radiosensitivity

\section{Introduction}

Laryngeal carcinoma is one of the most common head and neck cancer. Although recent new some functional surgeries have used in the treatment of laryngeal carcinoma, cancer statistics of American Cancer Society in 2013 showed that the trend in 5-year relative survival rate was descend from 1975 to 2008[1]. However, it is needed a new treatment strategy to improve the survival rate and preservation of laryngeal function in patients with laryngeal carcinoma. Radiotherapy plays an important role in early stage, recurrence and late stage of laryngeal carcinomas, however, these laryngeal carcinomas always resist to radiotherapy. Therefore, it is necessary to find some new methods to improve radiosensitivity of laryngeal carcinoma and decrease injury in normal tissues. 
The exact mechanism of the radioresistance of laryngeal carcinoma remains unclear. The possible mechanisms are multiple factors including tumour-cell proliferation, hypoxia and intrinsic radioresistance [2]. Among these, hypoxia is an important factor in radioresistance of laryngeal carcinoma. Recently, interest in the Warburg effect has escalated due to the proven utility of FDG-PET for imaging tumors in cancer patients [3]. Warburg effect is that the higher glucose metabolic rate in malignant tumor cells as compared to their nonmalignant counterparts even in aerobic glycolysis. Many studies [4-7], including ours [8], have revealed that glucose transporter-1(GLUT-1) plays a significant role in malignant glucose metabolism and that it might contribute to the increased FDG uptake.

Some authors consider GLUT-1 a possible intrinsic marker of hypoxia in malignant tumors [9-10]. In our previous studies, we have found that GLUT-1 expression was correlated with lymph node metastasis, poor survival, and clinical stage of head and neck carcinoma (HNC) [11] and increased GLUT-1 expression as an independent survival predictor in laryngeal carcinoma [12]. Some studies have demonstrated that increased GLUT-1 expression is associated with radioresistance [13-15]. These results suggest that GLUT-1 expression could be considered a marker of radioresistance in malignant tumours, such as squamous cell carcinoma of the oral cavity, squamous cell carcinoma of the esophagus and uterine cervical cancer. In our previous study, we revealed that GLUT-1 overexpression in vitro is associated with cell proliferation and increased glucose uptake by laryngeal carcinoma Hep-2 cells. Conversely, the suppression of GLUT-1 expression by antisense oligodeoxynucleotides (AS-ODNs) may decrease glucose uptake and inhibit the proliferation of Hep-2 cells [6]. Therefore, we first speculated that the inhibition of GLUT-1 expression in laryngeal carcinoma might improve the radiosensitivity of laryngeal carcinoma.

To test this hypothesis, we assessed whether the effect of GLUT-1 expression on radioresistance of laryngeal carcinoma and whether suppression of GLUT-1 expression by AS-ODNs may affect on the radiosensitivity of laryngeal carcinoma in vitro and in vivo.

\section{Materials and Methods}

\section{Cells, antibodies, and plasmids}

The laryngeal carcinoma Hep-2 cell line was purchased from the Cell Research Institute of Chinese Academy of Sciences (Shanghai, China). Chloroform, isopropyl alcohol, and anhydrous alcohol were purchased from Hangzhou Changzhen Chemical Plant
(Hangzhou, China). Agarose was purchased from Biowest (Spain). Trizol was purchased from Invitrogen (Carlsbad, CA, USA). Reverse transcriptase MMLV and TAQ enzyme were purchased from Promega (USA). DNA Marker DL2000, pcDNA3.1 vector, restriction endonucleases HindIII and XbaI, and $\mathrm{T}_{4}$ DNA ligase were purchased from TaKaRa Co. (Japan). Tween 20 and Ponceau $S$ were purchased from Sigma (USA). Primary antibody against GLUT-1 was purchased from Santa Cruz Biotechnology (CA, USA). Secondary antibodies donkey anti-rabbit and donkey anti-mouse, cell lysis, Supersignal West Femto Kit, and PMSF were purchased from Pierce (USA). Primers were synthesised by Invitrogen (CA, USA). Sequence of the entire coding regions of GLUT-1 was obtained from GenBank, and primers were designed using ClustalX and Omega 2.0 Applied Software.

Cell culture. Hep-2 cells were cultured in Dulbecco's modified Eagle's medium (DMEM; GIBCO-BRL, Gaithersburg, MD) containing 10\% heat-inactivated fetal bovine serum (FBS, Hyclone, Logan, UT), $2 \mathrm{mM}$ L-glutamine, 100U/ml penicillin, and $100 \mathrm{~g} / \mathrm{ml}$ streptomycin at $37^{\circ} \mathrm{C}$ in a $5 \% \mathrm{CO}_{2}$ atmosphere. Cells were trypsinised and harvested after reaching $80-90 \%$ confluence.

\section{Antisense oligonucleotides GLUT-I prepara- tion}

Generation of GLUT-1cDNA; construction of GLUT-1expression vector and antisense oligonucleotides. Total RNA was isolated from human Hep-2 laryngeal carcinoma cells as described [16]. Briefly, Reverse transcription (RT)-PCR was used to generate GLUT-1 complementary DNA (cDNA) from $800 \mathrm{ng}$ of total RNA. The product of the anti GLUT-1 or GLUT-1 pcDNA3.1 vector was digested with HindIII and XbaI, and cDNA was extracted from an agarose gel. After digestion, the cDNA was then subcloned into the vector pcDNA3.1 with $\mathrm{T}_{4}$ DNA ligase. The linked products were named pcDNA3.1-anti- GLUT-1 $(+)$ and pcDNA3.1- GLUT-1 (+). The transforming mixture was selected on LB agar plates with ampicillin $(100 \mathrm{mg} / \mathrm{L})$. To confirm positive clones, the recombinant plasmids pcDNA3.1-anti- GLUT-1 (+) and pcDNA3.1- GLUT-1 (+) were digested with HindIII and XbaI. The sequences of the amplified PCR products were then verified.

Cell culture and transfection with GLUT-1 antisense oligonucleotides or empty expression vector. When Hep-2 cells were in good condition and the numbers of cells were adequate, Hep-2 cells were seeded in 6-well plates at a density of $3.12 \times 10^{5}$ cells/well. After $24 \mathrm{~h}$, empty pcDNA3.1 vectors (mock transfection), pcDNA3.1-anti- GLUT-1 (+), or pcDNA3.1- GLUT-1 
(+) was transfected into Hep-2 cells using the Lipofectamine 2000 reagent (Invitrogen Co., Ltd., USA). The transfected quantity of each plasmid was $4 \mu \mathrm{g}$. Each group had three wells/plate according to the manufacturer's protocol. After $24 \mathrm{~h}$, the medium was replaced with $1200 \mu \mathrm{g} / \mathrm{mL}$ G418 medium. The cells in two of three non-transfected wells were replaced with $1200 \mu \mathrm{g} / \mathrm{mL}$ G418-selective medium. The medium was then replaced every 2 days until it was full of transfected cells in each of the 6-well plates. After cultured cells were propagated to passage to a $25-\mathrm{cm}^{2}$ cell culture flask, the cells were amplified. After the cells were amplified to some degree, some tubes of Hep-2 cells with different transfected plasmids were frozen, and then some cells were assayed.

DNA extraction and identification of transfection by $P C R$. DNA from each group was extracted using a TIANamp Genomic DNA Kit (Tiangen Biotech, DP304) according to the manufacturer's instructions. Briefly, the cells were harvested and transferred to a 1.5-mL microcentrifuge tube. They were centrifuged $(12,000 \mathrm{rpm}, 30 \mathrm{~s})$ to pellet the cells. The supernatant was then removed, and $500 \mu \mathrm{L}$ GD solution was added and centrifuged $(12,000 \mathrm{rpm}, 30 \mathrm{~s})$. The supernatant was removed, and $700 \mu \mathrm{L}$ bleaching lotion PW was added and centrifuged $(12,000 \mathrm{rpm}, 30 \mathrm{~s})$. After repeating the above step, the adsorbent column was placed back into the collecting pipe and centrifuged $(12,000 \mathrm{rpm}, 2 \mathrm{~min})$. The adsorbent column was placed into another clean centrifuge tube, $200 \mu \mathrm{L}$ elution buffer TE was added in the middle of the absorption film, the tube was left for 2-5 min at room temperature, and was centrifuged $(12,000 \mathrm{rpm}, 30 \mathrm{~s})$. The absorbent column was added to the centrifuged solutions, left for 2-5 minutes at room temperature, and centrifuged (12,000 rpm, $2 \mathrm{~min})$.

The extracted DNA was then verified by PCR. The sequences for the GLUT-1 sense and antisense primers were 5'-cccaagcttATGGAGCCCAGCAGCA AGAAG-3' and 5'-tgctctagaCACTTGGGAATCAGC CCCCAG-3'. The sequences for the anti- GLUT-1 sense and antisense primers were 5'-tgctctagaTTTATTGCAGCCAGAGCCACCAGCG-3 ' and 5'-cccaagcttACAGAAAAGATGGCCACTGAG3'. PCR was carried out under the following reaction conditions: Extracted DNA $(4 \mu \mathrm{L})$ was amplified in a $40-\mu \mathrm{L}$ reaction volume by PCR. The reaction volume included $10 \times$ buffer $(4 \mu \mathrm{L}), 10 \mathrm{mM}$ dNTP polymerase $(0.8 \mu \mathrm{L}), 25 \mathrm{mM} \mathrm{MgCl} 2(3.2 \mu \mathrm{L}), 5 \mathrm{U}$ Taq DNA polymerase $(0.3 \mu \mathrm{L})$, template $(4 \mu \mathrm{L})$, upstream and downstream specific primers $(0.5 \mu \mathrm{L})$, and deionised water $(26.7 \mu \mathrm{L})$. The parameters of the PCR cycles were as follows.

For GLUT-1pcDNA3.1 plasmid: The reaction mixture was first PR-denatured at $94^{\circ} \mathrm{C}$ for $3 \mathrm{~min}$, followed by 35 cycles at $94^{\circ} \mathrm{C}$ for $20 \mathrm{~s}, 61^{\circ} \mathrm{C}$ for $20 \mathrm{~s}$, and $72^{\circ} \mathrm{C}$ for $90 \mathrm{~s}$; and a final extension period at $72^{\circ} \mathrm{C}$ for $10 \mathrm{~min}$ and cooling at $4^{\circ} \mathrm{C}$ for $5 \mathrm{~min}$. RT-PCR products were visualised by agarose gel electrophoresis with ethidium bromide staining.

For anti- GLUT-1pcDNA3.1 plasmid: The reaction mixture was first PR-denatured at $94^{\circ} \mathrm{C}$ for $3 \mathrm{~min}$, followed by 35 cycles at $94^{\circ} \mathrm{C}$ for $20 \mathrm{~s}, 57^{\circ} \mathrm{C}$ for $20 \mathrm{~s}$, and $72^{\circ} \mathrm{C}$ for $30 \mathrm{~s}$; and a final extension period at $72^{\circ} \mathrm{C}$ for $10 \mathrm{~min}$ and cooling at $4^{\circ} \mathrm{C}$ for $5 \mathrm{~min}$. RT-PCR products were visualised by agarose gel electrophoresis with ethidium bromide staining.

\section{Cell incubation, $\mathbf{X}$-ray radiation before AS-OND transfection}

When Hep-2 cells were grown to $80 \%$ confluency, Hep-2 cells were divided into 5 groups. One is control group did not receive any $X$-ray radiation. Other group was received 2Gy, 4Gy, 8Gy, 12Gy X-ray radiation, respectively, and each group was cultured $24 \mathrm{~h}, 48 \mathrm{~h}$ and $72 \mathrm{~h}$, respectively. X-ray radiation was performed on accelerator linear (Clinac 23EX, Varian Company, USA). Source skin distance was 100 centimeter $(\mathrm{cm})$, radiation field was $35 \mathrm{~cm} \times 35 \mathrm{~cm}$, a single energy was $6 \mathrm{MV} \mathrm{X}$-ray and dose-rate was 500 $\mathrm{MU} / \mathrm{min}$. All assays were carried out in triplicate.

\section{Cell incubation, X-ray radiation after Hep-2 cells transfected with AS-OND}

Hep-2 cells were transfected with AS-ODN GLUT- 1 and continued to be cultured to $80 \%$ confluency. Transfected Hep-2 cells were also divided into 15 groups: control group, 2Gy, 4Gy, 8Gy, 12Gy X-ray radiation respectively, and each group was cultured $24 \mathrm{~h}, 48 \mathrm{~h}$ and $72 \mathrm{~h}$, respectively. The condition of X-ray radiation was described as above. All assays were carried out in triplicate.

\section{Analysis of the expression of GLUT-I mRNA by reverse transcription polymerase chain re- action (RT-PCR)}

Cells were homogenized in TRIzol reagent (Invitrogen, Carlsbad, CA). Total RNA was extracted from cells according to the manufacturer's protocol. The concentration of total RNA was measured by ultraviolet spectrophotometry; an optical density (OD) 260/280 ratio between 1.8 and 2.0 was deemed to be acceptably pure. Reverse transcription was performed according to the manufacturer's protocol. Briefly, the above product was amplified by PCR in a $40-\mu \mathrm{L}$ reaction volume consisting of $10 \times$ buffer $(4 \mu \mathrm{L})$, $10 \mu \mathrm{mol} / \mathrm{L}$ dNTP $(0.8 \mu \mathrm{L}), 25 \mathrm{mmol} / \mathrm{L} \mathrm{MgCl}_{2}(3.2 \mu \mathrm{L})$, $5 \mathrm{U}$ Taq DNA polymerase $(0.3 \mu \mathrm{L})$, template $(4 \mu \mathrm{L})$, upstream and downstream specific primers $(1 \mu \mathrm{L})$, and deionised water $(26.7 \mu \mathrm{L})$. The reaction mixture 
was first denatured at $94^{\circ} \mathrm{C}$ for $3 \mathrm{~min}$, followed by 30 cycles at $94^{\circ} \mathrm{C}$ for $1 \mathrm{~min}, 57^{\circ} \mathrm{C}$ for $30 \mathrm{~s}$, and $72^{\circ} \mathrm{C}$ for 30 $\mathrm{s}$; and a final extension period at $72^{\circ} \mathrm{C}$ for $10 \mathrm{~min}$. RT-PCR products were visualised by agarose gel electrophoresis with ethidium bromide staining. Selected sequences of primers were as follows: The sense and antisense primers of GLUT-1 were 5'-CCCAAGCTTATGGAGCCCAGCAGCAAGAAG$3^{\prime}$, and 5'-TGCTCTAGACACTTGGGAATCAGCC CCCAG-3', GAPDH were 5'-CCCAAGCTTATGGA GCCCAGCAGCAAGAAG- $3^{\prime}$ and $5^{\prime}$-TGCTCTAGAC ACTTGGGAATCAGCCCCCAG-3'.

\section{Analysis of the expression of GLUT-I protein by western blotting}

Western blotting was performed as described previously [17]. The GLUT-1 and $\beta$-actin (as a control) protein in each group of Hep-2 cells were assayed using a BAC protein quantitative kit (Wuhan Boster Biological Technology Co. Ltd., Wuhan China). Briefly, $80 \mu \mathrm{g}$ of protein was subjected to $10 \%$ sodium dodecyl sulfate-polyacrylamide gel electrophoresis (SDS-PAGE) and transferred onto a nitrocellulose membrane (Millipore, Billerica, MA, USA). Skimmed milk $(2 \%)$ was used as a blocking solution (room temperature, $1 \mathrm{~h}$ ). The membrane was incubated with the primary antibody (GLUT-1, 1:1000; $\beta$-actin, 1:5000) at room temperature for $3 \mathrm{~h}$, and with the secondary antibody (1:5000, donkey anti-rabbit; 1:2000, donkey anti-mouse) at room temperature for $1 \mathrm{~h}$. The proteins were detected using an enhanced chemiluminescence system (Santa Cruz Biotechnology, Santa Cruz, CA, USA) and were exposed to X-ray film. Protein expression was analyzed semi-quantitatively using the Kodak Gel Logic Analysis System.

\section{Proliferation assays of Hep-2 Cells using MTS}

Cell proliferation assays were performed using the CellTiter $96 \mathrm{H}$ AQueous Non-Radioactive Cell Proliferation Assay (MTS assay; Promega, Fitchburg, WI, USA) according to the manufacturer's protocol. 15 groups included control, 2Gy, 4Gy, 8Gy, 12Gy with or without transfected GLUT-1 24h, 48h, 72h after X-ray radiation, respectively. Briefly, each plate with $20 \mathrm{ul} /$ well MTS added were incubated at $37^{\circ} \mathrm{C}$ for up to 2 hours and were analyzed for $490 \mathrm{~nm}$ absorbance using a SpectroMAX 190 plate reader (Molecular Devices, Sunnyvale, CA, USA). Absorbance values from wells without cells (background) were subtracted from those of wells with cells.

\section{Cell cycle and apoptosis analysis using flow cytometry (FCM)}

Cells of above groups was trypsinized using $0.25 \%$ trypsin and rinsed in phosphate-buffered saline
(PBS). The cells were centrifuged at $800 \mathrm{~g}$ for $5 \mathrm{~min}$ and resuspended in up to 500- $\mu$ l PBS. The cells were divided into two tubes, one for cell cycle and one for apoptosis. One was centrifuged and cells were collected and fixed in ice-cold $70 \%$ ethanol for $24 \mathrm{~h}$ and recentrifuged. Cells were then incubated with RNase $(0.5 \mathrm{mg} / \mathrm{ml})$ and stained with $1 \mathrm{ml}$ of $50 \mathrm{u} \mathrm{g} / \mathrm{ml}$ propidium iodide (PI, Sigma Chemical Co., St. Louis, $\mathrm{MO}$ ) in the dark for $30 \mathrm{~min}$ at room temperature. Another was added 5ul FITC and 5ul PI, and incubated 15 minutes at $25^{\circ} \mathrm{C}$. Then cells were added $400 \mathrm{ul}$ buffer in the dark for 1 hour. Then FAC scan analysis system was used to collect FCM data on the change in cell cycle and cell apoptosis. Each experiment was performed three times in triplicate.

\section{In vivo studies}

This experiment was in accordance with institutional guidelines of the First Affiliated Hospital, College of Medicine, Zhejiang University and with appropriate institutional certification. Animal surgical and X-ray radiation were performed under general anesthesia, $50 \mathrm{mg} / \mathrm{kg}$ ip injection of pentobarbital sodium. Approximately $2 \times 10^{7}$ of Hep-2 cells were subcutaneously inoculated into the flanks of 4-week-old female athymic nude mice (BALB/c,) Tumor growth rates were determined by measuring two orthogonal dimensional diameters of each tumor thrice a week. Tumor volumes were calculated according to the formula $\mathrm{V}=1 / 2 \times \mathrm{a}^{2} \times \mathrm{b}$ ( $\mathrm{a}=$ short axis, $\mathrm{b}=$ long axis. When tumors reached an average volume of about $150 \mathrm{~mm}^{3}$, the tumor-bearing BALB/c-nu/nu mice were divided into two groups assigned 3 nude mice in each group: (a) irradiation group, tumors were exposed to X-ray of 8 Gy alone for each time; and (b) combination group, 100ug of GLUT-1 AS-ODNs was injected into the solid tumor three times (the interval time was 2 days) before $8 \mathrm{~Gy}$ $\mathrm{X}$-ray exposure. BALB/c-nu/nu mice were killed 12days later.

The GLUT-1mRNA of the tumor in the different groups was analyzed by real-time RT-RCR. Briefly, cells were homogenized in TRIzol reagent (Invitrogen, Carlsbad, CA). Total RNA was extracted from cells according to the manufacturer's protocol. The concentration of total RNA was measured by ultraviolet spectrophotometry; an optical density (OD) 260/280 ratio between 1.8 and 2.0 was deemed to be acceptably pure. Reverse transcription was performed according to the manufacturer's protocol. $1 \mu \mathrm{g}$ of total RNA and the Moloney Murine Leukemia Virus (MMLV) reverse transcriptase (Fermentas, Canada) in a $20-\mu \mathrm{l}$ reaction volume consisting of $0.5 \mu \mathrm{g} / \mu \mathrm{l}$ of oligo $\mathrm{d}(\mathrm{T})$ primer, $1 \mu \mathrm{l}$ of random primers $(0.2 \mu \mathrm{g} / \mu \mathrm{l})$, and $10 \mu \mathrm{l}$ of DEPC $\cdot \mathrm{H}_{2} \mathrm{O}$. The reaction mix was first 
pre-denatured at $65^{\circ} \mathrm{C}$ for $10 \mathrm{~min}$. After addition of 200 U M-MLV reverse transcriptase (Fermentas, Canada), the samples were incubated at $42^{\circ} \mathrm{C}$ for $1 \mathrm{~h}$ and annealed at $70^{\circ} \mathrm{C}$ for $10 \mathrm{~min}$. The above-synthesized cDNA was used as a template for real-time fluorescent quantitative PCR using the fluorescent dye SYBR Green and the Eppendorf Realplex4 real-time PCR system (Eppendorf Realplex4; Hamburg, Germany). The $20-\mu$ l reaction mix consisted of $10 \mu \mathrm{l}$ of $2 \times$ SYBR Green, $1 \mu \mathrm{l}$ of template, $1 \mu \mathrm{l}$ of upstream and downstream specific primers, and $8 \mu \mathrm{l}$ of deionized water. The reaction mix was pre-denatured at $95^{\circ} \mathrm{C}$ for $2 \mathrm{~min}$, followed by 40 cycles at $95^{\circ} \mathrm{C}$ for $15 \mathrm{~s}, 59^{\circ} \mathrm{C}$ for $20 \mathrm{~s}$, and $72^{\circ} \mathrm{C}$ for $20 \mathrm{~s}$. Each primer sample was run in triplicate. Selected sequences of primers were as follows: The sense and antisense primers of GLUT-1 were: 5'-CCGCAACGAGGAGAACCG-3', and 5'-GTGACC TTCTTCTCCCGCATC-3'; GAPDH(as control) were 5'-TGTTGCCATCAATGACCCCTT-3' and $5^{\prime}$ - TCCAC GACGTACTCAGCG-3'. The lengths of PCR products were $123 \mathrm{bp}$ (GLUT-1) and 202 bp (GAPDH).To distinguish between specific and non-specific products and primer dimers, dissociation curve analysis was conducted immediately after amplification by continuous monitoring of the SYBR Green I fluorescence signal at temperatures between $60^{\circ} \mathrm{C}$ and $95^{\circ} \mathrm{C}$. For calculation of differential gene expression, the $2^{-\Delta \Delta \mathrm{Ct}}$ formula was used

The GLUT-1 protein expression of the tumor in the different groups was analyzed by western blotting

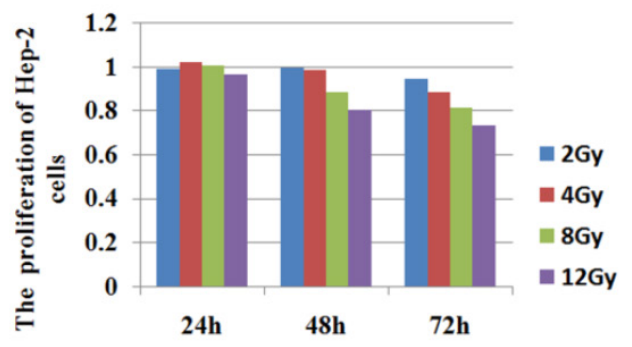

A

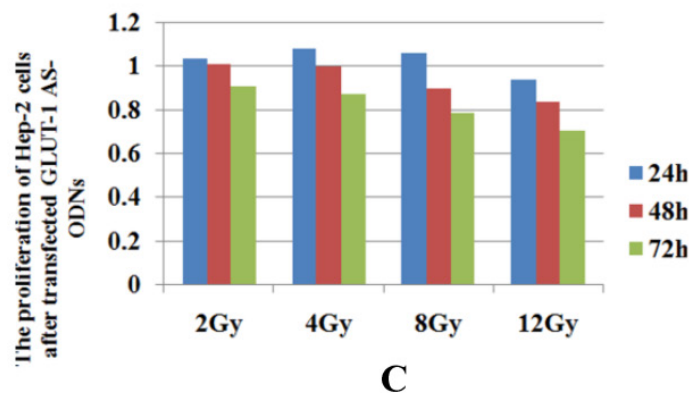

using the procedures described as above.

\section{Statistical analysis}

Statistical analyses were performed using SPSS for Windows (version 19.0 SPSS Inc., Chicago, IL). A P-value less than 0.05 was deemed to indicate statistical significance.

\section{Results}

\section{The effect of GLUT-I AS-ODNs on prolifera- tion of laryngeal carcinoma Hep-2 cells after radiation}

Before transfection, MTS showed that the proliferation of Hep-2 cells of 4Gy X-ray radiation was higher than control group, 2Gy, 8Gy and 12Gy X-ray radiation after 24 hours $(p<0.05)$. There was no significant difference in proliferation of Hep-2 cells among $2 \mathrm{~Gy}, 8 \mathrm{~Gy}$ and $12 \mathrm{~Gy} \mathrm{X}$-ray radiation after $24 \mathrm{~h}(\mathrm{p}>0.05)$. On $48 \mathrm{~h}$ after $\mathrm{X}$-ray radiation, there was no significant difference in the proliferation of Hep-2 cells between $2 \mathrm{~Gy}$ and $4 \mathrm{~Gy}$, respectively ( $\mathrm{p}>0.05)$. There was significant difference in the proliferation of Hep-2 cells between 2Gy, 4Gy and 8Gy, 12Gy, respectively $(\mathrm{p}<0.05)$. On $72 \mathrm{~h}$ after $\mathrm{X}$-ray radiation, there was no significant difference in the proliferation of Hep-2 cells between 2Gy and 4Gy, 4Gy and 8Gy, respectively $(p>0.05)$ (Figure 1A). There were no significant differences between the survival rates of groups with same radiation dose during different culture time $(24 h, 48 h, 72 h)(p>0.05$, Figure 1B).
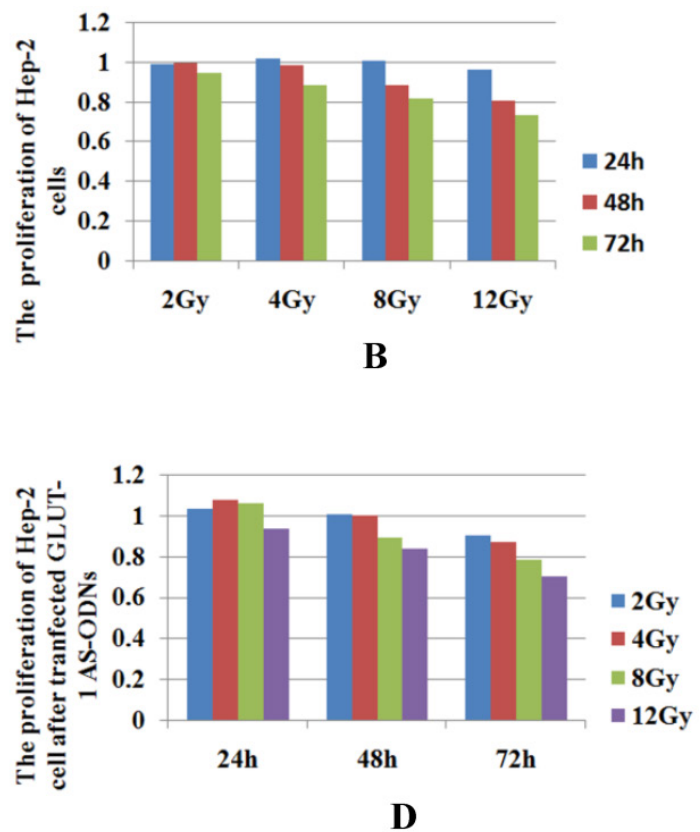

Figure I: The proliferation of Hep-2 cells by MTS. A: Before transfection, MTS showed that the proliferation of Hep-2 cells that underwent 4 Gy of X-ray radiation was higher than that of cells in the control group and of cells that underwent 2 , 8, or 12 Gy of $X$-ray radiation after $24 \mathrm{~h}(\mathrm{p}<0.05)$. At $48 \mathrm{~h}$ after $\mathrm{X}$-ray radiation, there was a significant difference in the proliferation of Hep-2 cells between those that underwent 2 and 4 Gy and between those that underwent 8 and I 2 Gy of X-ray radiation $(p<0.05)$. B: There were no significant differences between the survival rates of groups with the same radiation dose during different culture time $(24 \mathrm{~h}, 48 \mathrm{~h}, 72 \mathrm{~h})(\mathrm{p}>0.05)$. C: After transfection of GLUT-I AS-ODNs, MTS assay showed the survival rates of the radiation groups(2Gy,4Gy,8Gy andI2Gy) decreased gradually with increasing culture time $(p<0.05)$. D: At the same time, the cell survival rates decreased gradually with increasing of radiation dose $(p<0.05)$. 
After transfection of GLUT-1 AS-ODNs, MTS assay showed the survival rates of radiation groups(2Gy,4Gy,8Gy,12Gy)were gradually reduced with the prolongation of culture time $(p<0.05$, Figure $1 C)$; At the same time, cell survival rates were significantly reduced along with the increasing of radiation dose $(p<0.05$, Figure 1D ).

\section{The effect of GLUT-I AS-ODNs on radiore- sistance of laryngeal carcinoma Hep-2 cells}

To analyze the expression of GLUT-1 in mRNA and protein level in Hep-2 cells, RT-PCR and western blotting assay were used respectively.

$24 \mathrm{~h}$ after X-ray radiation, GLUT-1mRNA of Hep-2 cells in 2Gy, 4Gy and 8Gy were higher than that in control group before transfection $(p<0.05)$, the highest was in the $4 G y$ radiation group $(p<0.05$, Figure 2A).

$48 \mathrm{~h}$ after radiation, the expression of GLUT-1mRNA in 2Gy radiation group was higher than other groups before transfection $(p<0.05$, Figure $2 \mathrm{~A})$. There were no significant differences in the expression of GLUT-1mRNA between control group, $4 \mathrm{~Gy}$ radiation group, $8 \mathrm{~Gy}$ radiation group and $12 \mathrm{~Gy}$ radiation group, respectively ( $p>0.05$, Figure $2 A)$.

$72 \mathrm{~h}$ after radiation, the expressions of GLUT-1mRNA in 2Gy, 8Gy and 12Gy radiation group were higher than control group before transfection
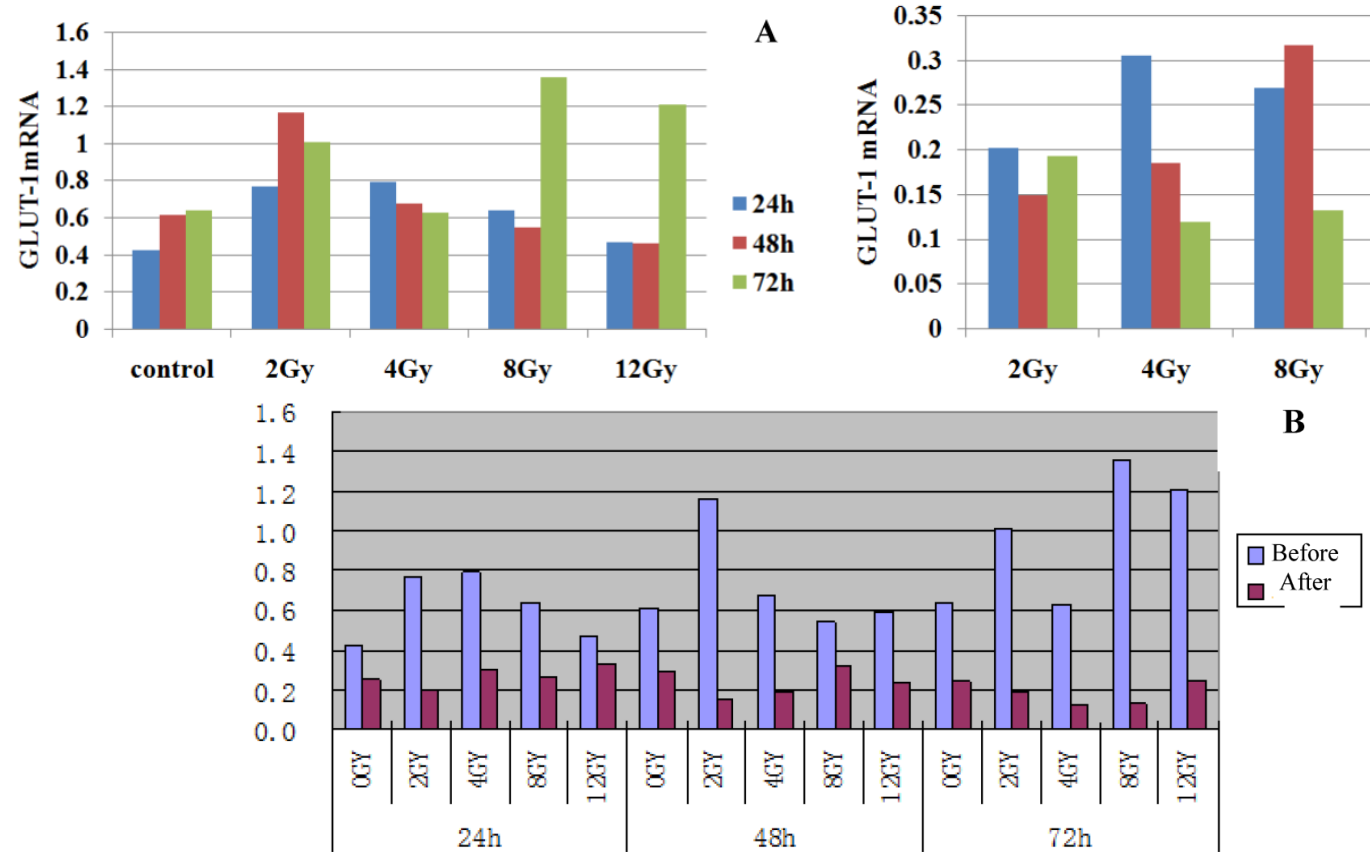

Figure 2: The expression of GLUT-I mRNA before and after transfection of GLUT-I AS-ODNs. A: At $24 \mathrm{~h}$ after X-ray radiation, the GLUT-I mRNA level of Hep-2 cells that received 2, 4, and $8 \mathrm{~Gy}$ of X-ray radiation was higher than that of cells in the control group before transfection. The highest level was detected in the 4-Gy radiation group $(p<0.05)$. At $48 \mathrm{~h}$ after radiation, the expression of GLUT-ImRNA in 2-Gy radiation group was higher than that in the other groups before transfection $(\mathrm{p}<0.05)$. There were no significant differences in the expression of GLUT-ImRNA among the control group, 4-, 8- and I2-Gy radiation groups $(p>0.05)$.At $72 \mathrm{~h}$ after radiation, the expressions of GLUT-ImRNA level in 2-, 8-, and I2Gy radiation group were higher than that in control group before transfection $(\mathrm{p}<0.05)$. B: After transfection of GLUT-I AS-ODNs, there was significant difference in the expression of GLUT-ImRNA between before and after X-ray radiation of identical dosage $(\mathrm{p}<0.05)$. C: The inhibitive effect of GLUT-I AS-ODNs was not significant at different $\mathrm{X}$-ray doses and different times after radiation. At $24 \mathrm{~h}$ after radiation, the expression of GLUT-I mRNA was not significantly altered by application of different radiation doses $(p>0.05)$. At $48 \mathrm{~h}$ after radiation, the expression of GLUT-I mRNA was significantly lower in the 2- and 4-Gy X-ray radiation groups than in the control group $(p<0.05)$. In the other groups, there was no difference. At $72 \mathrm{~h}$ after radiation, the expression of GLUT-I mRNA was not significantly different among the different X-ray radiation groups ( $p>0.05)$.

$(\mathrm{p}<0.05$, Figure $2 \mathrm{~A})$.

After transfection of GLUT-1 AS-ODNs, RT-PCR revealed that GLUT-1 AS-ODNs could inhibit the expression of GLUT-1 mRNA before X-ray radiation $(p<0.05$, Figure 2B). After transfection of GLUT-1 AS-ODNs, there was significant difference in the expression of GLUT-1mRNA in the same X-ray dose between before and after $\mathrm{X}$-ray radiation $(\mathrm{p}<0.05$, Figure 2B). However, the inhibitive effect of GLUT-1 AS-ODNs was not significant in the different X-ray dose and different time after radiation (Figure 2C). Only in 4Gy X-ray radiation, GLUT-1 mRNA expression was gradually decreased along with the prolongation of culture time $(p<0.05$, Figure $2 C)$. In other group, there was no significant difference in the expression of GLUT-1mRNA along with the prolongation of culture time ( $p>0.05$, Figure $2 C)$. 24 h after radiation, the expression of GLUT-1mRNA was not significant changed in different radiative dose ( $p>0.05$, Figure $2 \mathrm{C}$ ). $48 \mathrm{~h}$ after radiation, the expression of GLUT-1mRNA was significant decreased in 2Gy $\mathrm{X}$-ray radiation and $4 \mathrm{~Gy} \mathrm{X}$-ray radiation compared to control group, respectively ( $p<0.05$, Figure $2 C$ ). In other groups, there was no difference. $72 \mathrm{~h}$ after radiation, the expression of GLUT-1mRNA was not significant difference between different $\mathrm{X}$-ray radiation $(p>0.05$, Figure $2 C)$.

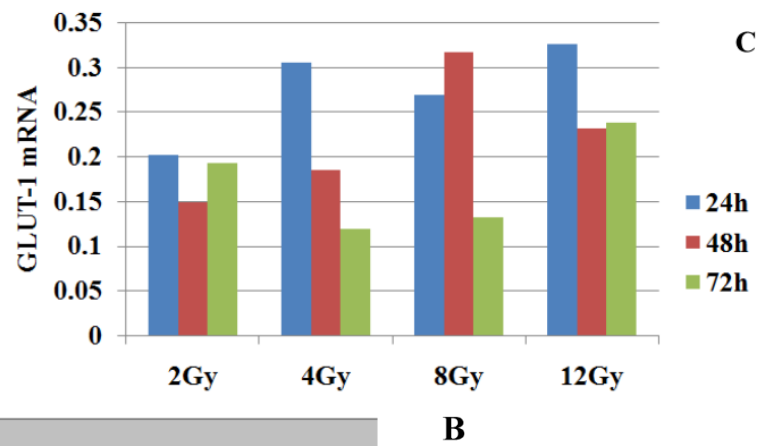


$24 \mathrm{~h}$ after radiation, western blotting showed expression of GLUT-1 protein in 2Gy, 4Gy and 12Gy group was higher than that in the control group before transfection $(p<0.05$, Figure $3 \mathrm{~A}, 3 \mathrm{~B})$, the expression of GLUT-1protein in 12Gy group was highest in all groups $(p<0.05$,Figure $3 \mathrm{~A}, 3 \mathrm{~B})$ whereas, the expression of GLUT-1protein in 8Gy was lowest in all groups $(\mathrm{p}<0.05$, Figure $3 \mathrm{~A}, 3 \mathrm{~B}) .48 \mathrm{~h}$ after radiation, the expression of GLUT-1 protein reached the zenith in all X-ray radiation groups before transfection of GLUT-1 AS-ODNs,(Figure 3A,3B). 72h after radiation, the expression of GLUT-1 protein fall before transfection (Figure 3A, 3B).

After transfection, the expression of GLUT-1 protein in the same radiation dose was reduced along with prolongation of culture time (Figure 3C,3D). $72 \mathrm{~h}$ after radiation, the expressions of GLUT-1protein in all radiation group were significant lower after tranfection of GLUT-1AS-ODNs than those in corresponding group before transfection $(p<0.05$, Figure 3E).

\section{Effect of GLUT-I AS-ODNs on cell cycle and apoptosis of Hep-2 cells}

Before transfection, FCM showed that cell cycle

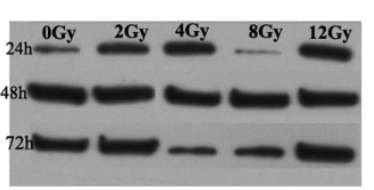

GLUT-1 protein

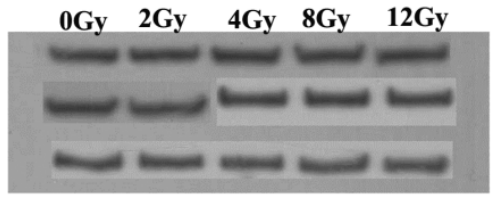

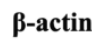

然

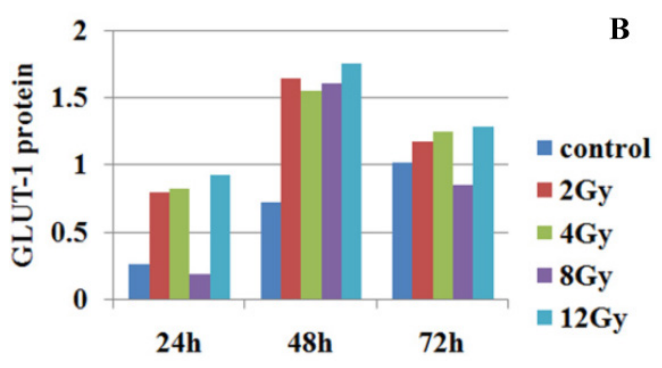

C

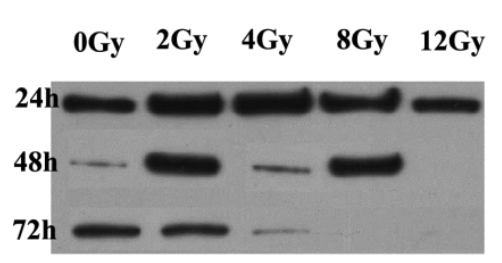

GLUT-1 protein

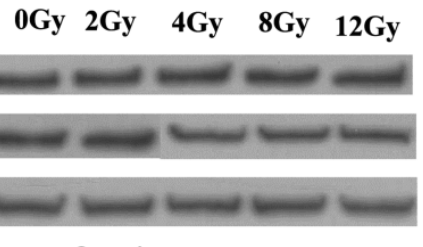

$\beta$-actin was changed from G1 phase to G2 phaseG2/M and arrested in $\mathrm{G} 2 / \mathrm{M}$ phase with increasing radiation dose at the same culture time, G2/M arrest in 12Gy group was up to maximum compared to other groups $(p<0.05$, Figure 4A).In same radiation dose at different culture time, cell cycle did not change. These results indicated that the change of cell cycle of Hep-2 cells was depended on radiation dose rather than culture time in this study.

After transfection, FCM also showed that cell cycle was changed from G1 phase to G2 phaseG2/M and arrested in $\mathrm{G} 2 / \mathrm{M}$ phase with increasing radiation dose at the same culture time, G2/M arrest in 12Gy group was up to maximum compared to other groups $(p<0.05$, Figure $4 B)$. The change was not significant difference between untransfected cells and transfected cells.

Apoptotic rates of Hep-2 cells after transfection were higher than these of Hep-2 cells before transfection $(p<0.05$, Figure $5 \mathrm{~A})$. After transfection, the more radiation dose increased and the more culture time was prolongated, the more apoptotic rates were detected (Figure 5B).

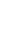
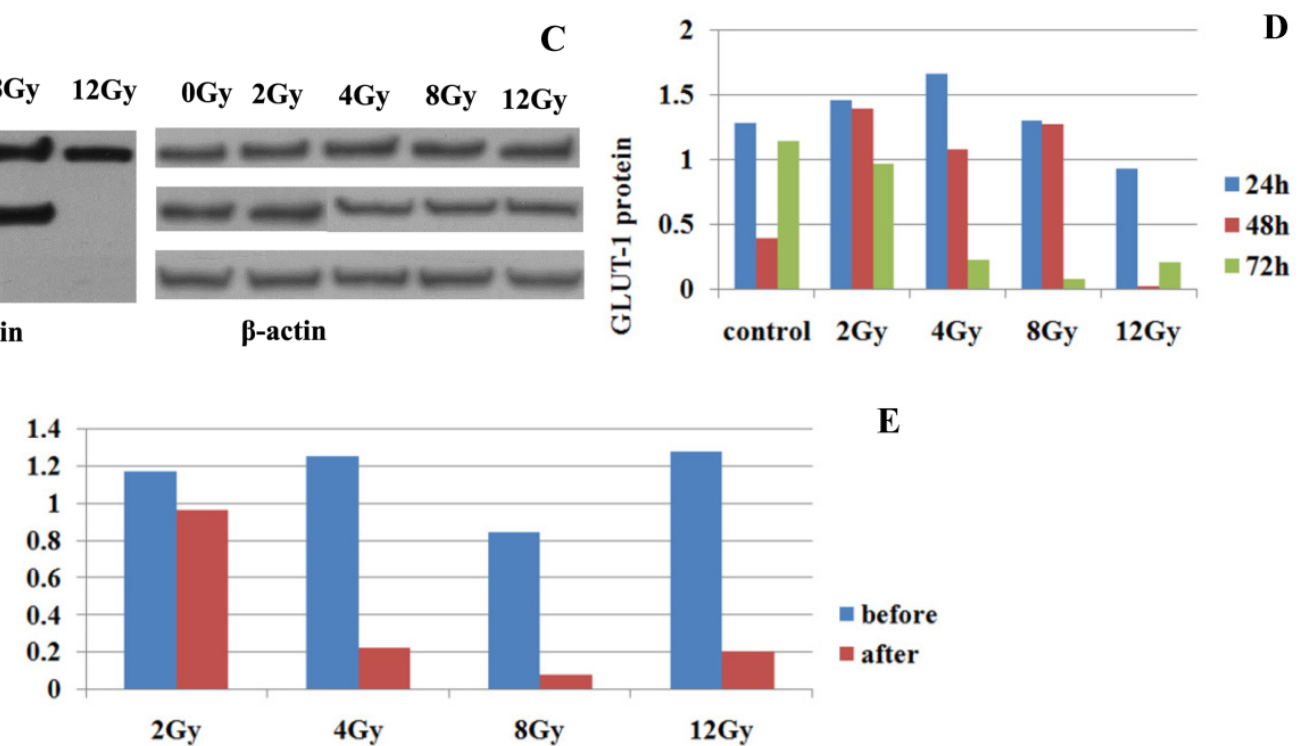

Figure 3: The expression of GLUT-I protein before and after transfection of GLUT-I AS-ODNs. A, B: At 24 h after radiation, western blotting showed that GLUT-I protein levels in 12-Gy group was highest. C,D: After transfection, the expression of GLUT-I protein at the same radiation dose decreased with increasing culture duration. E: At $72 \mathrm{~h}$ after radiation, GLUT-Iprotein levels in all radiation groups were significantly lower after tranfection of GLUT-IAS-ODNs than those before transfection $(p<0.05)$. 

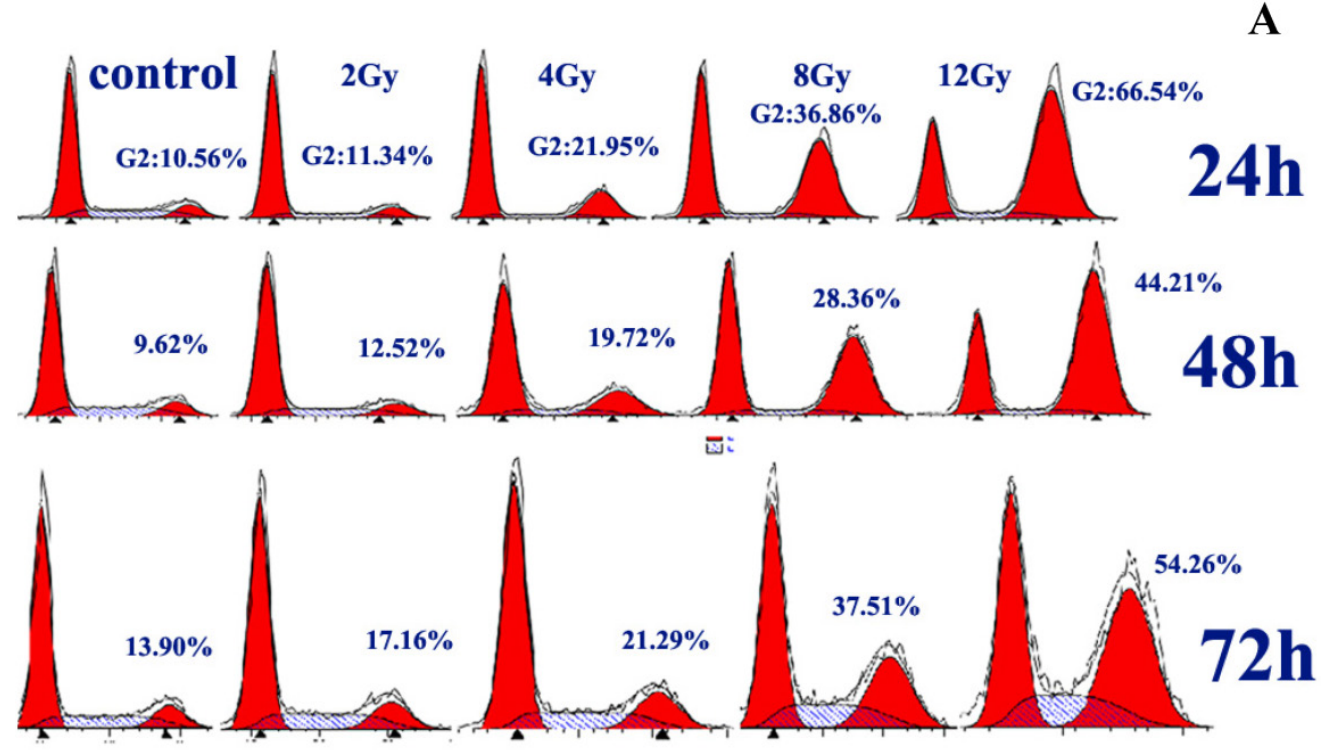

B

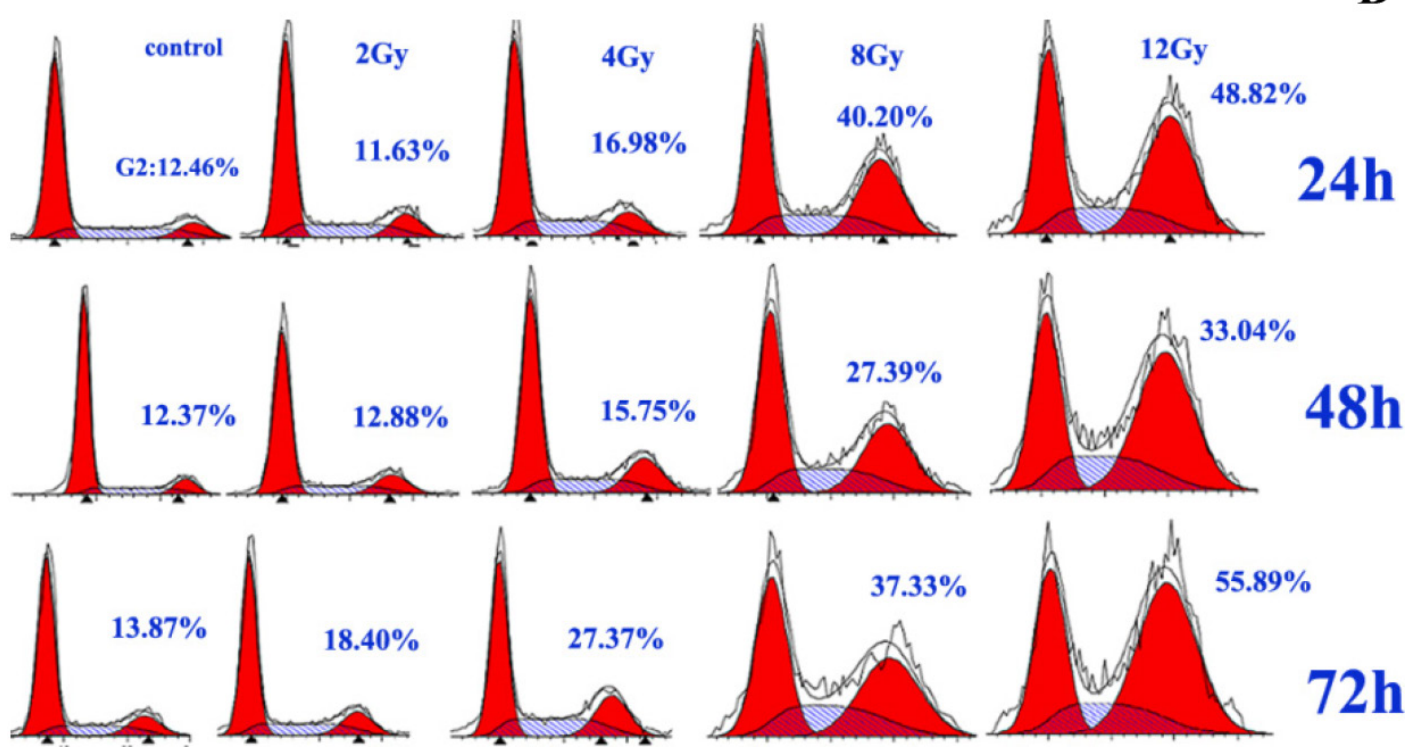

Figure 4: The change of cell cycle after radiation. A: Before transfection, the cell cycle had changed from GI phase to G2 phase and arrested in G2/M phase with an increasing radiation dose at identical culture duration. The G2/M arrest in the 12-Gy group was maximal compared with the other groups $(\mathrm{p}<0.05)$. At $24 \mathrm{~h}, 48 \mathrm{~h}$ and $72 \mathrm{~h}$, the G2/M arrest in the 12-Gy group was $66.54 \pm 9.55 \%, 44.21 \pm 0.28 \%, 54.26 \pm 2.78 \%$, respectively. B: After transfection, the changes of the cell cycle in different radiation dose and in different culture duration are similar as the changes before transfection. G2/M arrest in 12-Gy group was up to maxial compared with the other groups $(p<0.05)$. At $24 \mathrm{~h}, 48 \mathrm{~h}$ and $72 \mathrm{~h}, \mathrm{G} 2 / \mathrm{M}$ arrest in the 12 -Gy group was $48.82 \pm 6.34 \%, 33.04 \pm 6.61 \%, 55.89 \pm 4.37 \%$, respectively.

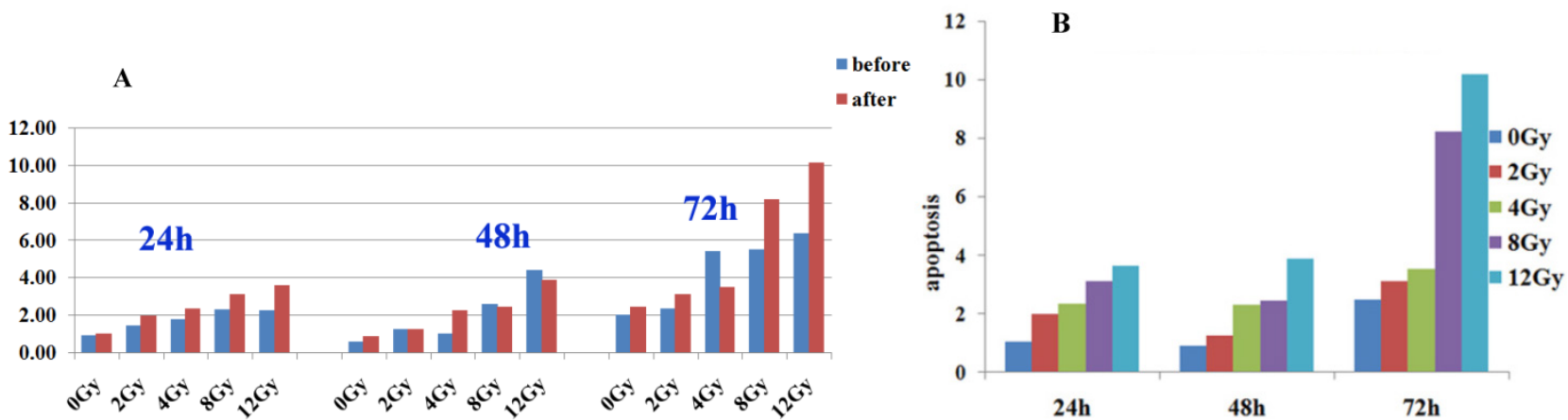

Figure 5: The apoptotic rates of Hep-2 cells before and after transfection. A: The apoptotic rates of Hep-2 cells after transfection were higher than these before transfection $(\mathrm{p}<0.05)$. B: Rates of apoptosis increased with increasing radiation dose and culture duration. 


\section{Effect of GLUT-I AS-ODNs on tumor growth in vivo after irradiation}

The volumes of xenograft tumor after 8Gy radiation plus transfection of GLUT-1 AS-ODNs were significant decreased when mouse were sacrificed compared to $8 \mathrm{~Gy}$ radiation alone, reducing mean tumor volume $>30 \%$ by 12 days after the initiation of treatment. When mouse were killed, the mean weight of tumors after 8Gy radiation plus transfection of GLUT-1 AS-ODNs was significant lower than that in mouse after $8 \mathrm{~Gy}$ radiation alone $(0.1553 \mathrm{~g} \pm 0.0874$ vs $0.9873 \mathrm{~g} \pm 0.2809, \mathrm{p}<0.001$,Figure $6 \mathrm{~A})$.

A
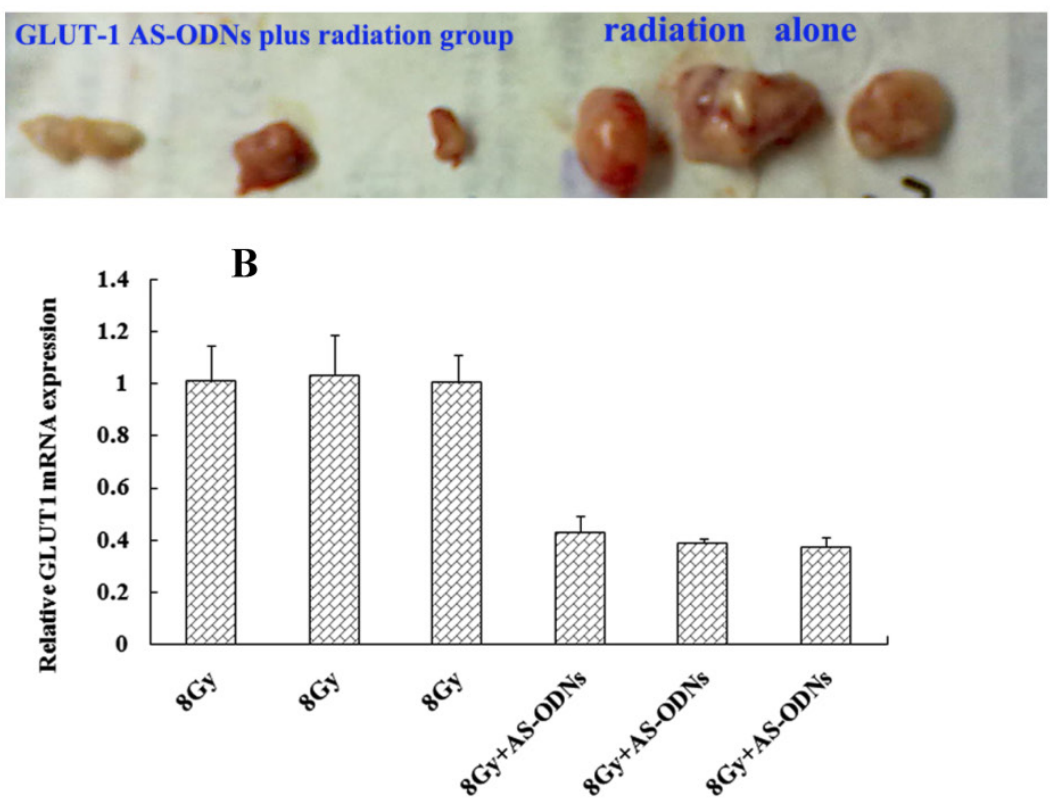

C

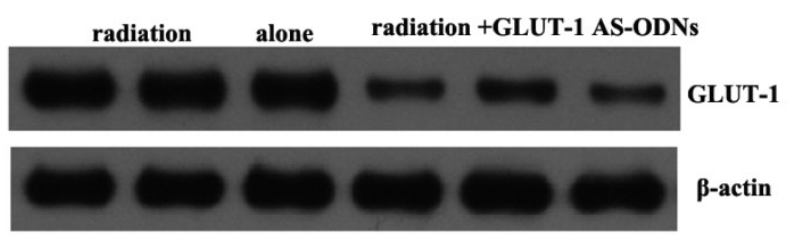

D

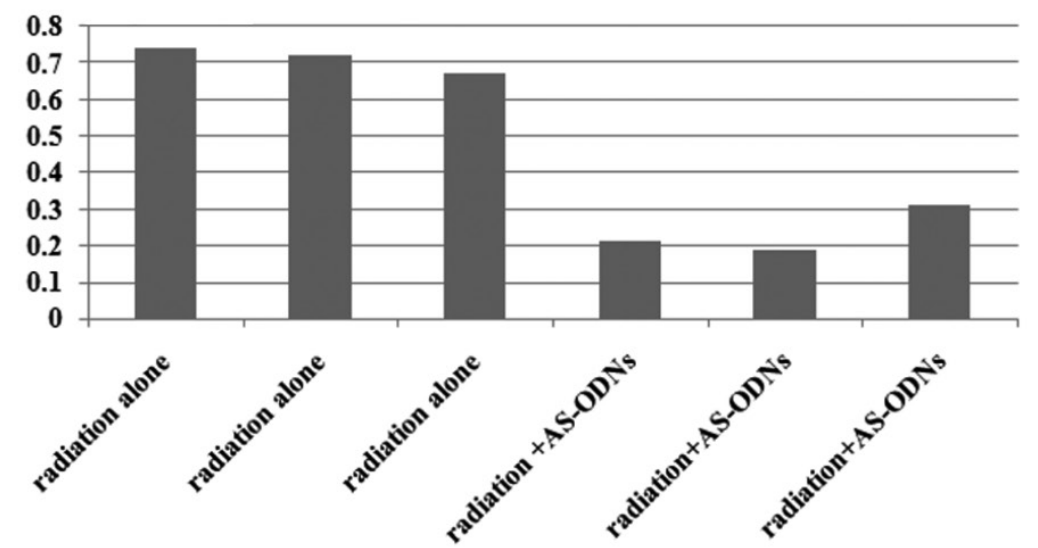

Figure 6: Effect of combined treatment with GLUT-I AS-ODNs plus radiation on xenograft tumor growth in vivo. A: representative tumors from each group. GLUT-I AS-ODNs plus radiation group had smaller volume than the control group. B: Real-time RT-PCR revealed that the relative expressions of GLUT-I mRNA after $8 \mathrm{~Gy}$ radiation alone in three mouse was $1.0068 \pm 0.1403,1.0306 \pm 0.1528,1.0038 \pm 0.1079$, respectively; The relative expressions of GLUT-I mRNA after $8 \mathrm{~Gy}$ radiation plus transfection of GLUT-I AS-ODNs in three mouse was $0.4284 \pm 0.0635,0.3880 \pm 0.0153,0.37$ I $6 \pm 0.0386$, respectively. C: Western blotting showed that the expressions of GLUT-I protein in xenograft tumors. D: Western blotting showed that the relative expressions of GLUT-I protein after 8 Gy radiation alone in three mouse was $0.7400 \pm 0.0353,0.7200 \pm 0.02876,0.6700 \pm 0.0109$,respectively; The relative expressions of GLUT-I protein after $8 G y$ radiation plus transfection of GLUT-I AS-ODNs in three mouse was $0.2100 \pm 0.0621$, $0.3100 \pm 0.0553,0.1900 \pm 0.0486$, respectively. 
Real-time RT-PCR revealed that the expressions of GLUT-1 mRNA after 8Gy radiation plus transfection of GLUT-1 AS-ODNs were significant decreased compared to $8 \mathrm{~Gy}$ radiation alone $(0.3960 \pm 0.0456$ vs $1.0137 \pm 0.1176, \mathrm{p}<0.001$, Figure 6B).

Western blotting also showed that the expressions of GLUT-1 protein after 8Gy radiation plus transfection of GLUT-1 AS-ODNs were significant decreased compared to $8 \mathrm{~Gy}$ radiation alone $(0.2367 \pm 0.0643$ vs $0.7100 \pm 0.0361, \mathrm{p}<0.001$, Figure $6 \mathrm{C}$, D).

\section{Discussion}

The exact mechanism of the radioresistance of laryngeal carcinoma remains unclear. Some studies have demonstrated that increased GLUT-1 expression is associated with radioresistance [13-15].These studies were retrospective analysis the expression of GLUT-1 in paraffin sections of patients with oral cancer[13], esophagus cancer [14] and uterine cervical cancer received radiotherapy by immunohistochemical study.

In this study, we found that the proliferation of Hep-2 cells did not markedly decrease with the increment of X-ray radiation dosage, whereas the proliferation of Hep-2 cells of 4Gy X-ray radiation was higher than control group, 2Gy $\mathrm{X}$-ray radiation after 24 hours $(p<0.05)$.We also found that there were no significant differences between the survival rates of groups with same radiation dose during different culture time $(24 h, 48 h, 72 h)$ ( $p>0.05)$. From above, we suggested that Hep-2 cells might reduce to radioresistance or insensitive to X-ray radiation. Further, we investigated this possible mechanism. To the best of our knowledge, this is the first report about the relationship between GLUT-1 expression and radioresistance. We found that the changes of GLUT-1 mRNA after different radiation dose and different culture time were similar as the changes of proliferation of Hep-2 cells after $X$-ray radiation. For example, the proliferation of Hep-2 cells of 4Gy X-ray radiation was higher than other groups after 24 hours. GLUT-1mRNA of Hep-2 cells in 4Gy was highest after $24 \mathrm{~h}$ culture $(p<0.05)$. Similar phenomena were detected in the expression of GLUT-1 proteins level. Therefore, we suggested that radioresistance or insensitive to X-ray radiation of Hep-2 cell might be associated with GLUT-1 mRNA and protein expression. However, the level of GLUT-1mRNA and protein did not follow a simple linear relationship. $48 \mathrm{~h}$ after radiation, the expression of GLUT-1 protein reached the zenith in all $\mathrm{X}$-ray radiation groups before transfection. We suggested that this inconsistent phenomenon might be different test time of GLUT-1 mRNA and protein. GLUT-1 mRNA had been de- graded when the expression of GLUT-1 protein was in peak or the expression of GLUT-1 protein was increasing when the expression of GLUT-1 mRNA was up to peak. Other mechanism may be that there is time and space interval in the gene expression of transcription and translation.

The mechanism of GLUT-1 expression causing radioresistance of Hep-2 cells remains unclear. The possible mechanisms include that the higher glucose metabolic rate in malignant tumor cells as compared to their nonmalignant counterparts even in aerobic glycolysis. Transport of glucose across the plasma membrane is the first rate-limiting step for glucose metabolism and is mediated by facilitative glucose transporter proteins [18]. GLUT-1 plays a significant role in malignant glucose metabolism and that it might contribute to the increased FDG uptake. GLUT-1 is a possible intrinsic marker of hypoxia in malignant tumors [9-10].Elevated GLUT-1 expression meets energy of malignant tumours and may lead to radioresistance. Secondly, hypoxia is common phenomenon in solid tumours including laryngeal carcinoma [12]. Hypoxia-inducible factor-1a (HIF-1a), a transcription factor associated with the cellular response to hypoxia [19], upregulates the expression of several hypoxia response genes, including GLUT-1[20]. We have first reported that a significant correlation between GLUT-1 and HIF-1a expression in laryngeal carcinoma [12]. We suggest that GLUT-1 expression is associated with laryngeal radioresistance through HIF-1a-regulated. Thirdly, GLUT-1 expression leads to laryngeal radioresistance may be through improving cell metabolism. Evans et al have revealed that GLUT-1 over-expression without a co-ordinate increase in HIF-1-regulated glycolytic enzymes increase glucose uptake rather than glycolytic rate [21]. They found that GLUT-1 lead to chemoresistance through increasing cell turnover [21]. Thus, we also speculate that the mechanism may be involved in the GLUT-1-mediated radioresistance. However, this hypothesis should be further studied in the future. Laryngeal cancer stem cell may be involved in the GLUT-1-mediated radioresistance. Ke et al. reported that GLUT-1 expression was higher in $\mathrm{CD}_{133^{+}}$than CD133- cells in thyroid cancer after ${ }^{131} \mathrm{I}$ radiotherapy [22]. Mai et al. reported that stem cells from proliferating hemangiomas may produce GLUT-1[23]. In our unpublished materials, we found that higher GLUT-1 mRNA and protein expression in $\mathrm{CD}_{133^{+}}$laryngeal carcinoma Hep-2 cells than in CD133-cells. However, this hypothesis should be also further studied in the future.

Cell cycle may play some role in the radioresistance [24-26]. G2/M phase arrest occurs in many cancer cells after irradiation [24-26]. In the present 
study, we found that a clear arrest of cells in the G2/M phase depending on radiation dose, which indicated entry into mitosis had been delayed. G2/M arrest in 12Gy group was up to maximum. These results were not similar with findings reported by Hematulin et al [26]. They reported that any phase of cell cycle of Hep-2 cells did not significantly change after irradiation and suggested that DNA damaged checkpoint predominantly G2 checkpoint of Hep-2 cells were not effective in response to radiation [26]. Therefore, the role of change of cell cycle in the radioresistance of Hep-2 cells should be future investigated.

Limited reports [27-32], including our report [16], antisense GLUT-1 may inhibit the proliferation of human tumour cells including laryngeal carcinoma cells [16,27-32]. Thus, it is of interest to investigate whether targeted AS-ODNs against GLUT-1 expression may enhance radiosensitivity of laryngeal carcinoma. In the present study, we found that GLUT-1 AS-ODNs had a synergy with $\mathrm{X}$-ray radiation in reducing the proliferation of Hep-2 cells in vitro. A single radiation dose (8Gy) on xenograft tumors dramatically reduced the growth rate of Hep-2 cells treated withGLUT-1 AS-ODNs. Corresponding to reducing the proliferation, GLUT-1 AS-ODNs could also cooperative with $\mathrm{X}$-ray radiation to decrease the expression of GLUT-1 protein of Hep-2 cells. This inhibitive effect increased along with time of transfection. The expression of GLUT-1 mRNA was also decreased in the same X-ray dose between before and after $\mathrm{X}$-ray radiation. However, the inhibitive effect of GLUT-1 AS-ODNs was not significant in the different $X$-ray dose and different time after radiation. These findings were not different with our previous results of Hep-2 cells without X-ray irradiation [16]. In previous study, we found that GLUT-1 mRNA suppression by GLUT-1 AS-ODNs was corresponding with decrease of GLT-1protein expression in Hep-2 cells without irradiation [16]. The possible reasons about the non-linear relationship between the level of GLUT-1mRNA and protein had mentioned as above. However, in vivo, we found that there was a clear linear relationship between decrease of GLUT-1 mRNA expression and reduction of GLUT-1 protein expression in laryngeal xenograft carcinoma treated with GLUT-1 AS-ODNs plus a single radiation dose. The difference between the results of GLUT-1 mRNA expression and GLUT-1 protein expression in vitro and in vivo may be different environment and different radiation strategies in vitro and in vivo in the present study.

We also found that there was synergy between GLUT-1 AS-ODNs and X-ray radiation in the apoptosis of Hep-2 cells. The more radiation dose increased and the more culture time was prolongated, the more apoptotic rates were detected. However, GLUT-1 AS-ODNs did not alter the cell cycle of Hep-2 cells after radiation.

\section{Conclusion}

To the best of our knowledge, this is first report about the relationship between GLUT-1 expression and radioresistance of laryngeal carcinoma. We found that radioresistance of laryngeal carcinoma may be associated with increased expression of GLUT-1 mRNA and protein. GLUT-1 AS-ODNs may enhance the radiosensitivity of laryngeal carcinoma mainly by inhibition of the expression of GLUT-1 protein and increasing of apoptosis of Hep-2 cells in vitro. In vivo, GLUT-1 AS-ODNs may enhance the radiosensitivity of laryngeal carcinoma mainly by inhibition of the expression of GLUT-1 mRNA and protein.

\section{Acknowledgements}

This research was supported by National Natural Science Foundation of China (No. 81172562), Science and Technology Department of Zhejiang Province, China (No. 2009C33026), Health Department of Zhejiang Province (No.2010KYA062 and 2009B042), and Department of Education of Zhejiang Province, China (No. Y201121184).

\section{Competing Interests}

The authors have declared that no competing interest exists.

\section{References}

1. Siegel R, Naishadham D, Jemal A. Cancer statistics, 2013. CA Cancer J Clin. 2013; 63:11-30.

2. Bussink J, van der Kogel AJ, Kaanders JH. Activation of the PI3-K/AKT pathway and implications for radioresistance mechanisms in head and neck cancer. Lancet Oncol. 2008; 9:288-96.

3. Bensinger SJ, Christofk HR. New aspects of the Warburg effect in cancer cell biology. Semin Cell Dev Biol. 2012; 23: 352-61.

4. Han MW, Lee HJ, Cho KJ, et al. Role of FDG-PET as a biological marker for predicting the hypoxic status of tongue cancer. Head Neck. 2012;34:1395-402

5. Alakus H, Batur M, Schmidt M, et al. Variable 18 F-fluorodeoxyglucose uptake in gastric cancer is associated with different levels of GLUT-1 expression. Nucl Med Commun. 2010;31:532-8.

6. Nagamatsu A, Umesaki $\mathrm{N}, \mathrm{Li} \mathrm{L}$, Tanaka $\mathrm{T}$. Use of 18F-fluorodeoxyglucose positron emission tomography for diagnosis of uterine sarcomas. Oncol Rep. 2010;23:1069-76.

7. Li XF, Ma Y, Sun X, Humm JL, Ling CC, O'Donoghue JA. High 18F-FDG uptake in microscopic peritoneal tumors requires physiologic hypoxia. J Nucl Med. 2010;51:632-8.

8. Li LF, Zhou SH, Zhao K, et al. Clinical significance of FDG single-Photon emission computed tomography: computed tomography in the diagnosis of head and neck cancers and study of its mechanism. Cancer Biother Radiopharm. 2008; 23: 701-4.

9. Luo XM, Zhou SH, Fan J. Glucose transporter-1 as a new therapeutic target in laryngeal carcinoma. J Int Med Res. 2010;38:1885-92.

10. Rademakers SE, Lok J, van der Kogel AJ, Bussink J, Kaanders JH. Metabolic markers in relation to hypoxia; staining patterns and colocalization of pimonidazole, HIF-1a, CAIX, LDH-5, GLUT-1, MCT1 and MCT4. BMC Cancer. 2011; 11:167.

11. Zhou S, Wang S, Wu Q, Fan J, Wang Q. Expression of glucose transporter-1 and -3 in the head and neck carcinoma--the correlation of the 
expression with the biological behaviors. ORL J Otorhinolaryngol Relat Spec. 2008;70:189-94.

12. Wu XH, Chen SP, Mao JY, Ji XX, Yao HT, Zhou SH. Expression and significance of hypoxia-inducible factor-1a and glucose transporter-1 in laryngeal carcinoma. Oncol Lett. 2012; 5: 261-6.

13. Kunkel M, Moergel M, Stockinger M, et al. Overexpression of GLUT-1 is associated with resistance to radiotherapy and adverse prognosis in squamous cell carcinoma of the oral cavity. Oral Oncol. 2007,43:796-803.

14. Doki Y, Takachi K, Ishikawa O, et al. Reduced tumor vessel density and high expression of glucose transporter 1 suggest tumor hypoxia of squamous cell carcinoma of the esophagus surviving after radiotherapy. Surgery. 2005; 137:536-44.

15. Markowska J, Grabowski JP, Tomaszewska K, et al. Significance of hypoxia in uterine cervical cancer. Multicentre study. Eur J Gynaecol Oncol. 2007; 28:386-8.

16. Zhou SH, Fan J, Chen XM, Cheng KJ, Wang SQ. Inhibition of cell proliferation and glucose uptake in human laryngeal carcinoma cells by antisensecoligonucleotides against glucose transporter-1. Head Neck. 2009; 31:1624-33

17. $\mathrm{Xu} Y Y$, Bao YY, Zhou SH, Fan J. Effect on the expression of MMP-2, MT-MMP in laryngeal carcinoma Hep-2 cell line by antisense glucose transporter-1. Arch Med Res. 2012; 43:395-401.

18. Krzeslak A, Wojcik-Krowiranda K, Forma E, et al. Expression of GLUT1 and GLUT3 glucose transporters in endometrial and breast cancers. Pathol Oncol Res. 2012;18:721-8.

19. Pez F, Dayan F, Durivault J, et al. The HIF-1-inducible lysyl oxidase activates HIF-1 via the Akt pathway in a positive regulation loop and synergizes with HIF-1 in promoting tumor cell growth. Cancer Res. 2011;71: 1647-57

20. Yasuda M, Miyazawa M, Fujita M, et al. Expression of hypoxia inducible factor-1alpha (HIF-1alpha) and glucose transporter-1 (GLUT-1) in ovarian adenocarcinomas: difference in hypoxic status depending on histological character. Oncol Rep. 2008; 19:111-6.

21. Evans A, Bates V, Troy H,et al. Glut- 1 as a therapeutic target: increased chemoresistance and HIF-1-independent link with cell turnover is revealed through COMPARE analysis and metabolomic studies. Cancer Chemother Pharmacol. 2008; 61: 377-93.

22. Ke CC, Liu RS, Yang AH, et al. CD133-expressing thyroid cancer cells are undifferentiated, radioresistant and survive radioiodide therapy. Eur J Nucl Med Mol Imaging. 2013;40:61-71.

23. Mai HM, Zheng JW, Wang YA, et al. CD133 selected stem cells from proliferating infantile hemangioma and establishment of an in vivo mice model of hemangioma. Chin Med J (Engl). 2013; 126: 88-94.

24. Xie G, Zhan J, Tian Y,et al. Mammosphere cells from high-passage MCF7 cell line show variable loss of tumorigenicity and radioresistance. Cancer Lett. 2012;316:53-61.

25. Gogineni VR, Nalla AK, Gupta R, Dinh DH, Klopfenstein JD, Rao JS. Chk2-mediated G2/M cell cycle arrest maintains radiation resistance in malignant meningioma cells. Cancer Lett. 2011;313:64-75.

26. Hematulin A, Meethang S, Ingkaninan K, Sagan D. Derris scandens Benth extract potentiates radioresistance of Hep-2 laryngeal cancer cells. Asian Pac J Cancer Prev. 2012;13:1289-95.

27. Chen $\mathrm{CP}, \mathrm{Li} X X$, Zhang LR, et al. Synthesis of antisense oligonucleotide-peptide conjugate targeting to GLUT-1 in HepG-2 and MCF-7 Cells. Bioconjug Chem. 2002;13:525-9.

28. Choi JW, Yoon DJ, Lee HW, Han DP, Ahn YH. Antisense GLUT1 RNA suppresses thetransforming phenotypes of NIH $3 \mathrm{~T} 3$ cells transformed by N-Ras. Yonsei Med J. 1995; 36: 480-6.

29. Chan JY, Kong SK, Choy YM, Lee CY, Fung KP. Inhibition of glucose transporter gene expression by antisense nucleic acids in HL-60 leukemia cells. Life Sci. 1999; 65: 63-70.

30. Noguchi $Y$, Saito A, Miyagi Y, et al. Suppression of facilitative glucose transporter 1 mRNA can suppress tumor growth. Cancer Lett. 2000; 154: 175-82.

31. Ito S, Nemoto T, Satoh S, Sekihara H, Seyama Y, Kubota S. Human rhabdomyosarcoma cells retain insulin-regulated glucose transport activity through glucose transporter 1. Arch Biochem Biophy.s 2000; 373: 72-82.

32. Liu TQ, Fan J, Zhou L, Zheng SS. Effects of suppressing glucose transporter-1 by an antisense oligodeoxynucleotide on the growth of human hepatocellular carcinoma cells. Hepatobiliary Pancreat Dis Int. 2011; 10: 72-7. 